\title{
Article \\ Analysis of Ion-Exchanged ZSM-5, BEA, and SSZ-13 Zeolite Trapping Materials under Realistic Exhaust Conditions
}

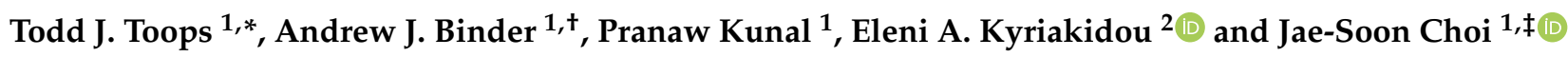 \\ 1 National Transportation Research Center, Oak Ridge National Laboratory, Knoxville, TN 37932, USA; \\ binder.andrewj@gmail.com (A.J.B.); kunalp@ornl.gov (P.K.); jaesoonchoi@lgchem.com (J.-S.C.) \\ 2 Department of Chemical and Biological Engineering, The State University of New York, \\ Buffalo, NY 14260, USA; elenikyr@buffalo.edu \\ * Correspondence: toopstj@ornl.gov \\ + Currently at Galbraith Laboratories Inc. \\ $\ddagger$ Currently at LG Chem Ltd.
}

Citation: Toops, T.J.; Binder, A.J.; Kunal, P.; Kyriakidou, E.A.; Choi, J.-S. Analysis of Ion-Exchanged ZSM-5, BEA, and SSZ-13 Zeolite Trapping Materials under Realistic Exhaust Conditions. Catalysts 2021, 11, 449. https://doi.org/10.3390/catal11040449

Academic Editor: Philippe Vernoux

Received: 4 March 2021

Accepted: 26 March 2021

Published: 31 March 2021

Publisher's Note: MDPI stays neutral with regard to jurisdictional claims in published maps and institutional affiliations.

Copyright: (c) 2021 by the authors. Licensee MDPI, Basel, Switzerland. This article is an open access article distributed under the terms and conditions of the Creative Commons Attribution (CC BY) license (https:// creativecommons.org/licenses/by/ $4.0 /)$.

\begin{abstract}
An industry-defined evaluation protocol was used to evaluate the hydrocarbon trapping (HCT) and passive NOx adsorption (PNA) potential for BEA, ZSM-5, and SSZ-13 zeolites with ionexchanged Pd or Ag. All materials underwent $700{ }^{\circ} \mathrm{C}$ degreening prior to exposure to an industryderived protocol gas stream, which included NOx, ethylene, toluene, and decane as measured trapping species as well as common exhaust gasses $\mathrm{CO}, \mathrm{H}_{2} \mathrm{O}, \mathrm{O}_{2}, \mathrm{CO}_{2}$, and $\mathrm{H}_{2}$. Evaluation showed that BEA and ZSM-5 zeolites were effective at trapping hydrocarbons (HCs), as saturation was not achieved after 30 min of exposure. SSZ-13 also stored HCs but was only able to adsorb 20-25\% compared to BEA and ZSM-5. The presence of Ag or Pd did not impact the overall HC uptake, particularly in the first three minutes. Pd/zeolites had significantly lower THC release temperature, and it aided in the conversion of the released HCs; Ag only had a moderate effect in both areas. With respect to NOx adsorption, the level of uptake was much lower than HCs on all samples, and Ag or Pd was necessary with Pd being notably more effective. Additionally, only Pd/ZSM-5 and $\mathrm{Pd} / \mathrm{SSZ}-13$ continue to store a portion of the NOx above $200{ }^{\circ} \mathrm{C}$, which is critical for downstream selective catalytic NOx reduction (SCR). Hydrothermal aging $\left(800{ }^{\circ} \mathrm{C}\right.$ for $50 \mathrm{~h}$ ) of a subset of the samples were performed: BEA, Pd/BEA, ZSM-5, Pd/ZSM-5, and Pd/SSZ-13. There was a minimal effect on the HC storage, $\sim 10 \%$ reduction in capacity with no effect on release temperature; however, only Pd/SSZ-13 showed significant NOx storage after aging.
\end{abstract}

Keywords: hydrocarbon trap (HCT); passive NOx adsorber (PNA); silver; palladium; zeolite

\section{Introduction}

Since the 1970s automotive emissions control has been a continual challenge due to increasing understanding of the hazards of pollutants and subsequently increasing regulatory efforts to lower harmful emissions. Initially, much of the lean-burn automotive emissions reduction was handled through emissions-conscious engine design and the use of a diesel oxidation catalyst (DOC) [1-7]. However, modern lean-burn emissions control requires a complex approach involving a series of specialized materials [8-14] to manage the wide variety of pollutants and exhaust conditions due to the increasingly strict emissions standards. These include diesel particulate filters (DPF) and selective catalytic NOx reduction catalysts (SCR), in addition to the DOC.

This emissions control system requires a minimum exhaust temperature to become fully effective, and thus, a significant percentage of the overall emissions occur in the first 1-2 min after starting the engine [15-17]. Additionally, improved engine efficiency results in cooler exhaust [18-21], such that under low load operation the exhaust and catalyst temperatures could temporarily decrease to the point the catalysts are not active in the 
emissions control system [20]. In most cases temperatures less than $200{ }^{\circ} \mathrm{C}$ would be considered a significant challenge for emissions control catalysts [20]. This temperature is typical for DOCs to be able to convert greater than $90 \%$ of the exhaust CO and total hydrocarbons (THCs), and above this temperature urea can be injected, which will hydrolyze to $\mathrm{NH}_{3}$ and is used to reduce NOx over the SCR. Development of a solution to these low temperature emissions control challenges is crucial to meeting future emissions requirements [21,22].

One frequently proposed approach to reducing low temperature emissions is the introduction of trapping materials within the emissions control system that would be capable of adsorbing HC and NOx until the catalysts have warmed up enough to become reactive [16,23-27]. Development of effective trapping materials often focuses on three primary factors: (i) a significant adsorption capacity at low temperatures $\left(<200^{\circ} \mathrm{C}\right)$, (ii) a desorption temperature compatible with emissions control active windows (greater than $200{ }^{\circ} \mathrm{C}$ ), and (iii) suitable durability against hydrothermal aging. With these factors in mind, a variety of zeolites have shown great promise in studies for the adsorption of common exhaust components such as CO, light and heavy HCs [26-30], and NOx species [31-34]. Unfortunately, many fundamental studies are often conducted in simplified gas streams which result in many questions as to their applicability to automotive systems which can include high concentrations of water and $\mathrm{CO}_{2}$, multiple types of $\mathrm{HC}$ species, $\mathrm{NOx}, \mathrm{CO}$, and high space velocity. On the other end of the research spectrum, industrially relevant studies are performed with full exhaust gas from engines [35-37]. These realistic evaluations show how the materials would work in the application, but the hundreds of different HCs in the exhaust make it difficult to track the individual components. Thus, evaluation of potential trapping materials under complex, yet manageable flow constituents, is necessary to prove feasibility, highlight challenges, and identify which family of exhaust components are most challenging.

With that in mind, we present an evaluation of nine zeolite-based trapping materials utilizing a flow reactor protocol developed by a collaboration of industry, national laboratories, and academic researchers [38,39] to mimic realistic lean-burn automotive exhaust. As described in detail below, this protocol includes the opportunity to simultaneously trap CO, NOx, and three HCs representative of those found in automotive exhaust: ethylene (shortchain alkenes), toluene (aromatics), and decane (long-chain alkanes). ZSM-5, BEA, and SSZ-13 zeolites and two ion-exchange metals, Pd or Ag, were chosen for this study based on previous reports of high storage efficiency and suitable release temperatures [40-46]. The representative structure of each of these zeolites are shown in Figure 1. Evaluation of both the storage and release characteristics of these materials was performed to elucidate the attributes of each material.

ZSM-5

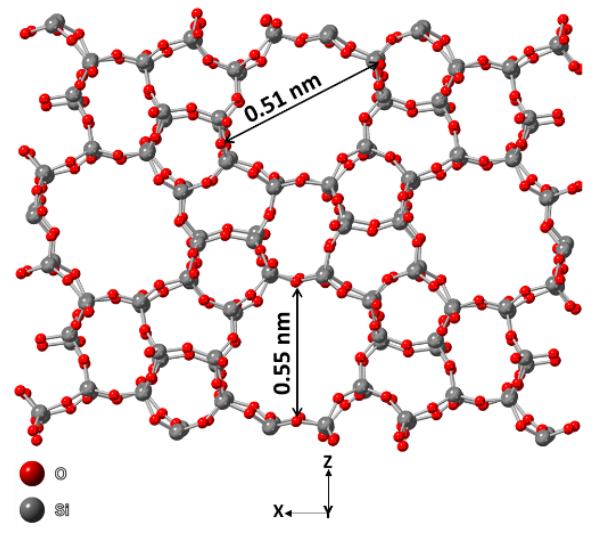

BEA

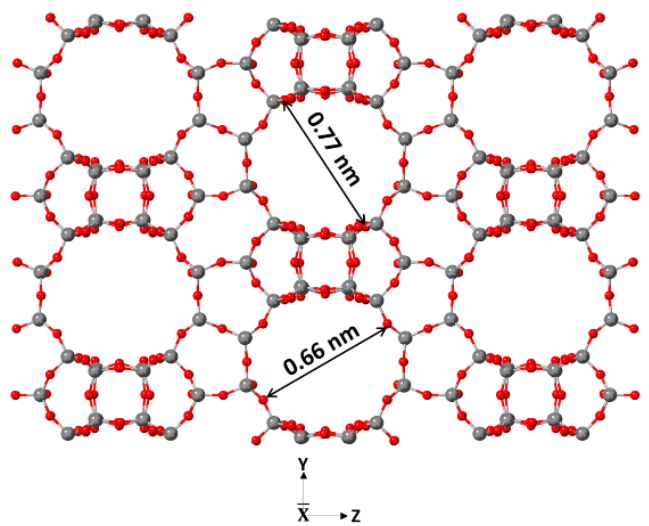

SSZ-13

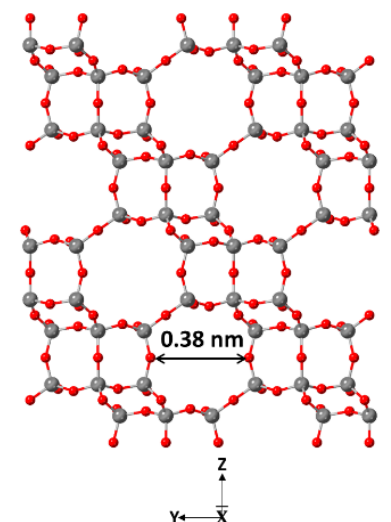

Figure 1. Representation of zeolite structures deployed in this study. 


\section{Results and Discussion}

\subsection{Hydrocarbon Trapping}

An ideal hydrocarbon trap (HCT) would have high storage below $200{ }^{\circ} \mathrm{C}$ and release HCs above $200{ }^{\circ} \mathrm{C}$ where a DOC could oxidize them to $\mathrm{CO}_{2}$ and $\mathrm{H}_{2} \mathrm{O}$. To understand how the evaluated samples meet these HCT criteria, a systematic analysis routine was employed. Figure 2 shows a characteristic storage and release profile for each of the three trials on $\mathrm{Pd} / \mathrm{ZSM}-5$. The difference between the reactor effluent and the bypass gas concentration indicates a large amount of storage on this sample, and we have analyzed this storage in 2 parts. The first portion is $3 \mathrm{~min}$ and is related to how much storage would be expected under a typical startup condition $[47,48]$. It is represented by the blue shading with white dots ( in Figure 2a and is quantified in Figure 2b. The second portion up to $30 \mathrm{~min}$ is

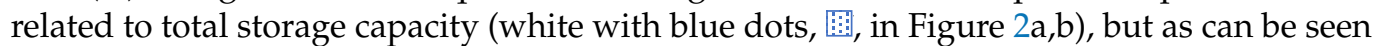
here, the sample was not fully saturated as the bypass concentration was not reached. After the 30-min storage, the reactant gases are turned off, and the sample is quickly heated to $600{ }^{\circ} \mathrm{C}$. During this portion of the experiment the HCs desorb from the sample, and some of them react to form $\mathrm{CO}$ and $\mathrm{CO}_{2}$. As suggested by the protocol [38,39], the release profile is described by three characteristic temperatures. The first is the temperature of $10 \%$ release (T10), i.e., the temperature where $10 \%$ of the observed desorbed HCs were released. This is also shown in Figure $2 \mathrm{a}$ with a dark blue shading $(\square)$ beginning at $30 \mathrm{~min}(0 \%$ release) and continuing to $\sim 33 \mathrm{~min}$ (10\% release); the temperature is also indicated with a dark blue arrow. Figure $2 \mathrm{c}$ indicates this value with the dark blue $(\square)$ portion of the bar. The next segment indicates the temperature of 50\% release (T50). In Figure 2a this is represented with the medium blue shading $(\square)$ that reaches from $10 \%$ to $50 \%$ and the temperature is indicated with medium blue arrow and by the second section of the bar in Figure 2c ( $\square$ ). The next segment of interest is for $90 \%$ release of the HCs, which is represented by a light blue shading $(\square)$ for the $50-90 \%$ release in Figure 2a. The T90 is represented by a light blue arrow in Figure 2a and the top segment of the bar in Figure 2c ( $\square)$.

This approach is used for each of the samples evaluated, and the full bar charts for both $\mathrm{HC}$ storage values (mmols $\mathrm{C}_{1} / \mathrm{g}_{\mathrm{cat}}$ ) and release temperatures for the degreened samples are shown in Figure 3 with the values listed in Table 1. All the BEA and ZSM-5 samples have similar uptake during the first 3 min with an uptake of $0.9-1.0 \mathrm{mmols} C_{1} / g_{\text {cat }}$. The SSZ-13 samples have notably less uptake with only $0.6-0.7 \mathrm{mmols} \mathrm{C}_{1} / \mathrm{g}_{\text {cat }}$ occurring in the first $3 \mathrm{~min}$. After $30 \mathrm{~min}$ the BEA samples store between 4.8 and $5.1 \mathrm{mmols} C_{1} / \mathrm{g}_{\text {cat }}$ while the ZSM- 5 samples have slightly less uptake of $4.3-5.0 \mathrm{mmols} \mathrm{C}_{1} / \mathrm{g}_{\text {cat }}$. The SSZ-13 samples reach saturation well before $30 \mathrm{~min}$ and only uptake a total of $0.9-1.0 \mathrm{mmols} \mathrm{C}_{1} / \mathrm{g}_{\text {cat }}$ after $30 \mathrm{~min}$. These results clearly indicate that the larger pore structures associated with BEA $(0.7-0.8 \mathrm{~nm})$ and ZSM-5 $(0.5-0.6 \mathrm{~nm})$ allow more uptake of the HCs studied here compared to SSZ-13 $(\sim 0.4 \mathrm{~nm})$, which has smaller pores [49,50]. An additional observation is that the presence of $\mathrm{Ag}$ or Pd does not generally result in higher uptake of the HCs in any of these samples. The one exception to this observation is that Ag/ZSM-5 uptakes 5.0 mmols $C_{1} / g_{\text {cat }}$ compared to $4.3-4.4$ for the other ZSM-5 samples. Enhanced uptake capacity in the presence of $\mathrm{Ag}$ has been reported elsewhere $[27,40,51]$, so it is interesting that we do not observe it in this study. A likely explanation is the large size and concentration of the decane molecule used here overwhelming the adsorption sites and zeolite pores; most prior work reporting these benefits of metals focused on shorter hydrocarbon lengths $[27,40,51,52]$. 


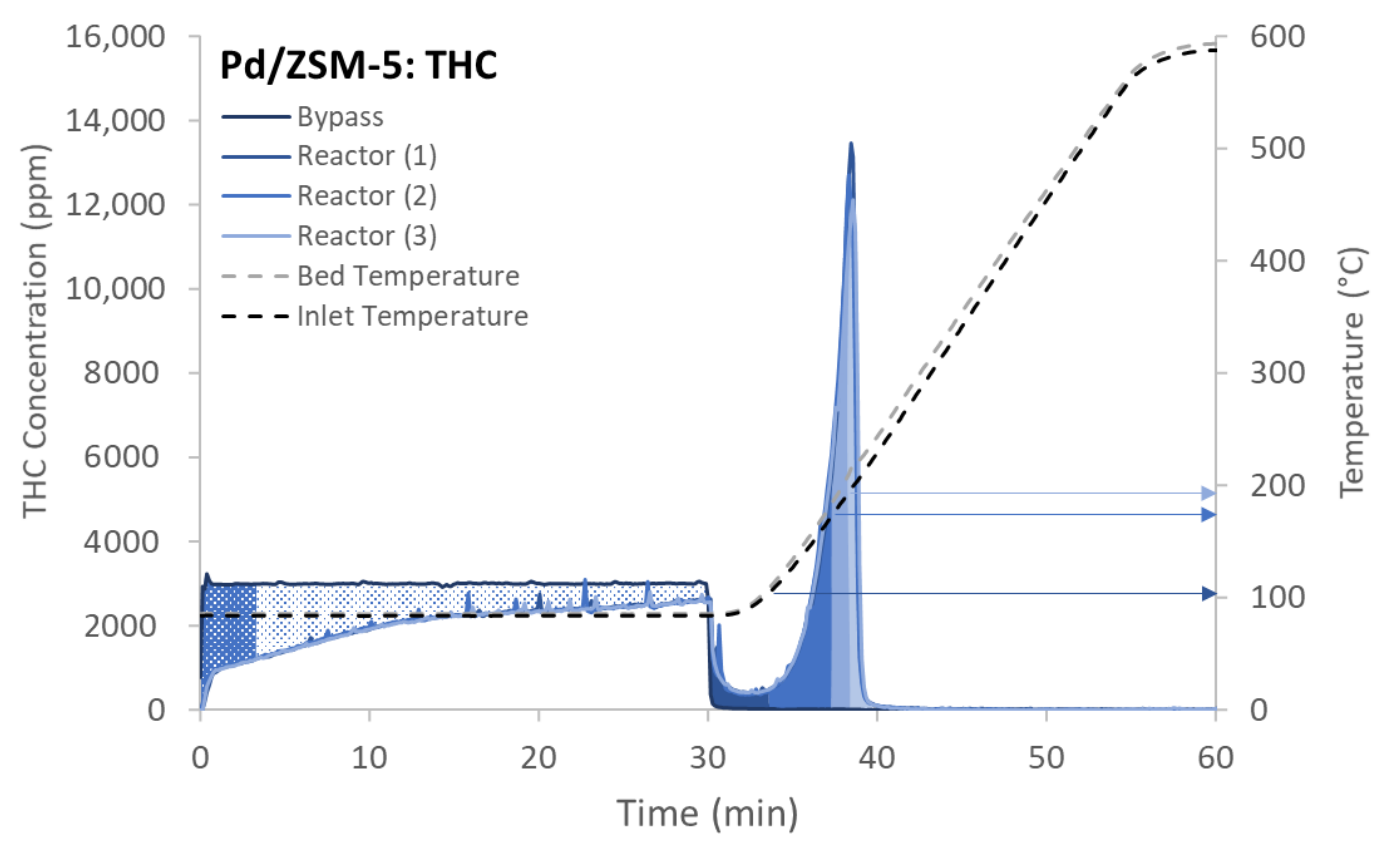

(a)

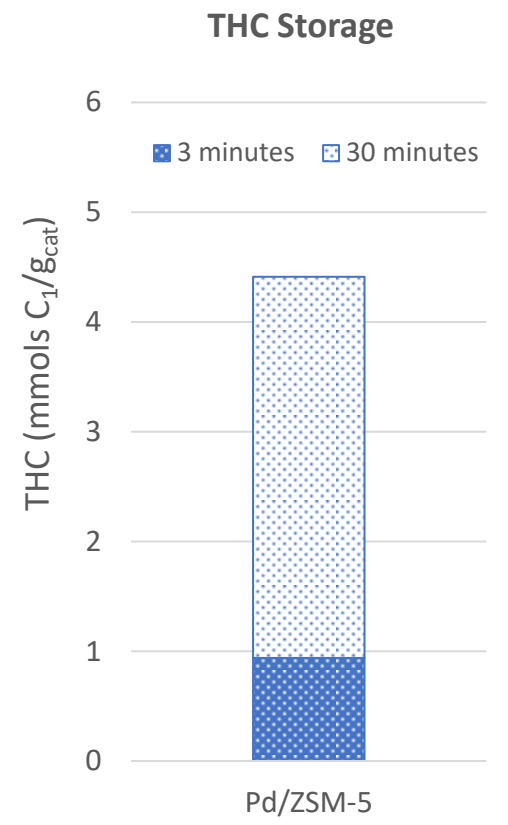

(b)
THC Release Temp.

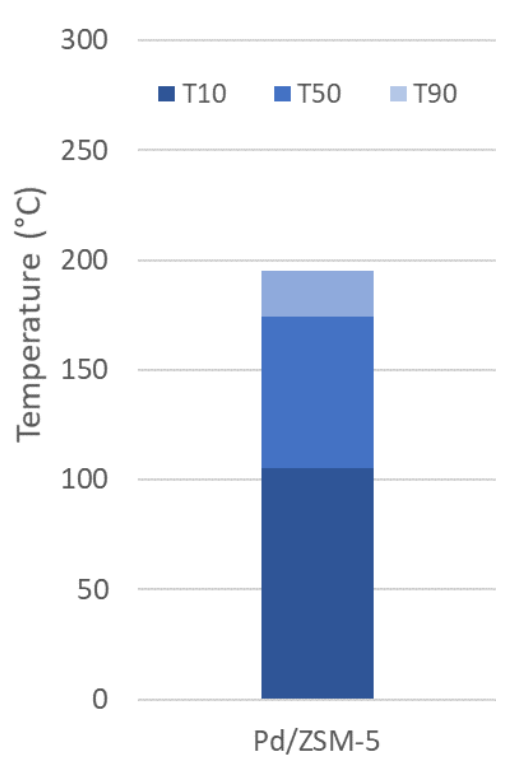

(c)

Figure 2. (a) THC concentration for each of the three reactor evaluations throughout the 60 min experiment. The shading

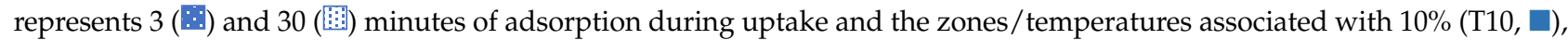
$50 \%$ (T50, $\square$ ), or $90 \%$ (T90, $\square$ ) of THC released during desorption, which are also indicated with arrows. These characteristics are then represented by bar charts for both (b) adsorption and (c) desorption. 


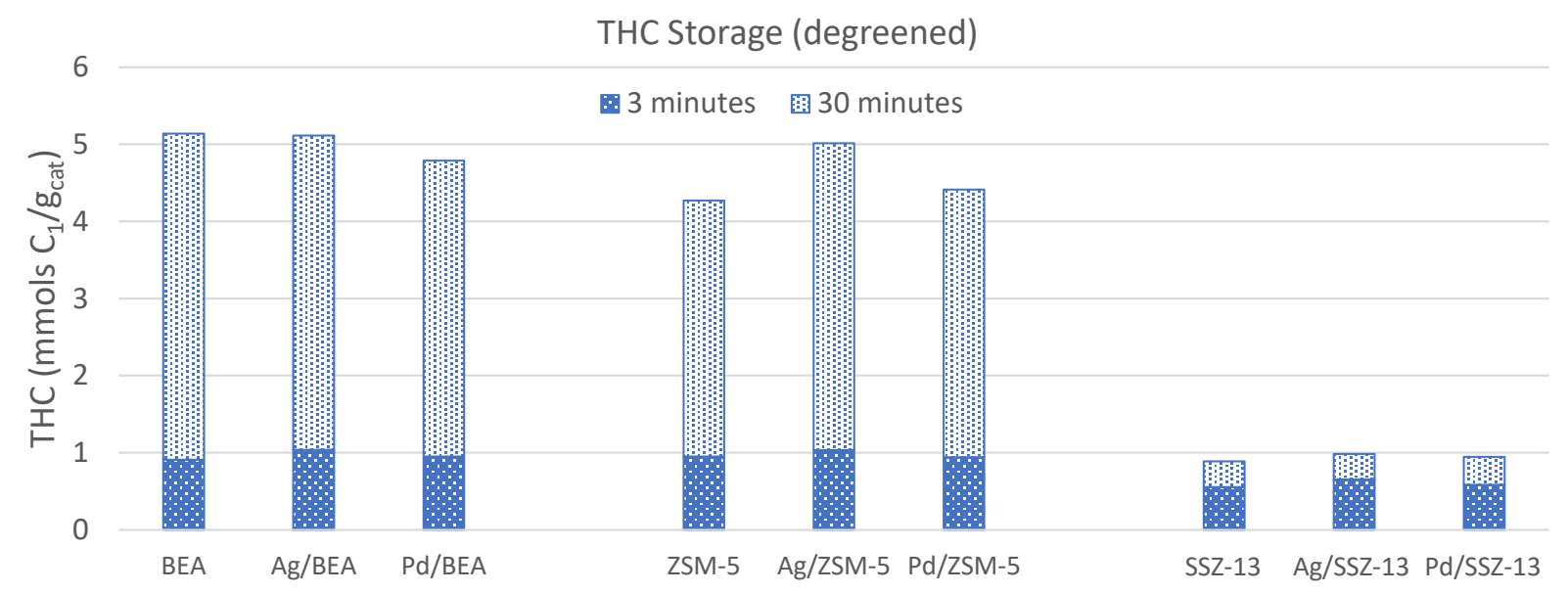

(a)

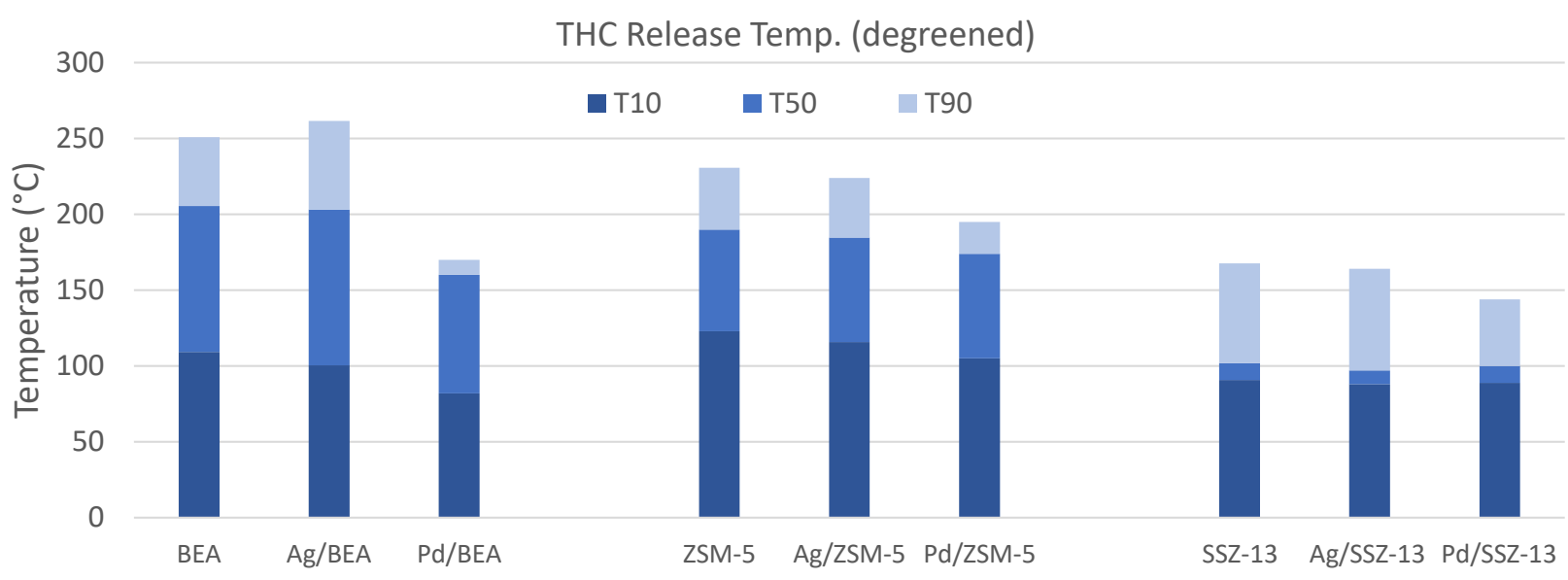

(b)

Figure 3. (a) THC adsorption after 3 ( ) and 30 (姬) minutes for each of the materials studied. (b) The temperature where $10 \%(\mathrm{~T} 10, \square), 50 \%(\mathrm{~T} 50, \square)$, or $90 \%(\mathrm{~T} 90, \square)$ of THC is released.

Table 1. THC storage values ( $\mathrm{mmol} / \mathrm{g}_{\text {cat }}$ ) for ion-exchanged zeolites during lean trapping evaluation after 3 and $30 \mathrm{~min}$; THCs are reported on a $C_{1}$ basis. The total amount of observed THC released during the first 15 min of the ramp, and the temperature where $10 \%$ (T10), 50\% (T50), or $90 \%$ (T90) of THC is released is also shown.

\begin{tabular}{|c|c|c|c|c|c|c|}
\hline \multirow{3}{*}{$\begin{array}{l}\text { LTC-D (Storage) } \\
\text { Degreened Zeolite }\end{array}$} & \multirow{2}{*}{\multicolumn{2}{|c|}{$\begin{array}{l}\text { THC Storage } \\
\left.\text { (mmols } \mathrm{C}_{1} / \mathrm{g}_{\text {cat }}\right)\end{array}$}} & \multirow{3}{*}{$\begin{array}{c}\text { THC Release } \\
\left.\text { (mmols } \mathrm{C}_{1} / \mathrm{g}_{\text {cat }}\right) \\
15 \mathrm{~min}\end{array}$} & \multicolumn{3}{|c|}{ Release Temperature } \\
\hline & & & & \multirow{2}{*}{$\begin{array}{l}\mathrm{T} 10 \\
\left({ }^{\circ} \mathrm{C}\right)\end{array}$} & \multirow{2}{*}{$\begin{array}{l}\mathrm{T} 50 \\
\left({ }^{\circ} \mathrm{C}\right)\end{array}$} & \multirow{2}{*}{$\begin{array}{l}\mathrm{T} 90 \\
\left({ }^{\circ} \mathrm{C}\right)\end{array}$} \\
\hline & $3 \mathrm{~min}$ & $30 \mathrm{~min}$ & & & & \\
\hline BEA & 0.9 & 5.1 & 5.2 & 109 & 205 & 251 \\
\hline $\mathrm{Ag} / \mathrm{BEA}$ & 1.0 & 5.1 & 4.5 & 101 & 203 & 262 \\
\hline $\mathrm{Pd} / \mathrm{BEA}$ & 1.0 & 4.8 & 2.0 & 82 & 160 & 170 \\
\hline ZSM-5 & 1.0 & 4.3 & 4.7 & 123 & 190 & 231 \\
\hline $\mathrm{Ag} / \mathrm{ZSM}-5$ & 1.0 & 5.0 & 5.0 & 116 & 185 & 224 \\
\hline Pd/ZSM-5 & 0.9 & 4.4 & 3.8 & 105 & 174 & 195 \\
\hline SSZ-13 & 0.6 & 0.9 & 1.0 & 91 & 102 & 168 \\
\hline Ag/SSZ-13 & 0.7 & 1.0 & 1.0 & 88 & 97 & 164 \\
\hline $\mathrm{Pd} / \mathrm{SSZ}-13$ & 0.6 & 0.9 & 0.8 & 89 & 100 & 144 \\
\hline
\end{tabular}

At the end of the storage phase, a portion of the HCs is released, but most of them stay adsorbed until higher temperatures. The temperature of $10 \%$ release (T10) is shown in 
Figure 3 and listed in Table 1, and there are no distinct trends across the nine samples other than that the Pd/zeolites have the lowest T10. Comparing T50s and T90s, the Pd/zeolites continue to show lower release temperatures for the BEA and ZSM- 5 samples. Since a small quantity of HCs are adsorbed on the SSZ-13 samples direct comparisons with BEA and ZSM-5 are difficult, but the trend of T90 being the lowest on the Pd sample is consistent. One of the confounding factors in evaluating the samples as we describe here, is that $\mathrm{Pd}$ is an excellent oxidation catalyst and the released $\mathrm{HCs}$ are readily oxidized over these zeolites in the presence of excess $\mathrm{O}_{2}$ [40]. Thus, even though $90 \%$ of the $\mathrm{HCs}$ are released below the previously mentioned goal of $200{ }^{\circ} \mathrm{C}$, the ability to convert the HCs directly on the HCT is a desirable feature. The released HC quantity is listed in Table 1, and in each Pd containing sample the released $\mathrm{HC}$ is less than the quantity stored at $30 \mathrm{~min}$. This is most apparent in the Pd/BEA where nearly $60 \%$ of the released HC is converted. This feature could possibly allow for a smaller DOC, or at least less PGM content to balance the PGM being used in the HCT; this is the focus of a future study of ours. It should be noted that although Ag is not an excellent oxidation catalyst, it is expected to catalyze a portion of the stored HCs, and there is evidence of this in the Ag/BEA sample with $12 \%$ less HCs observed during the release compared to the uptake. Another key observation in the release temperatures is that both BEA and Ag/BEA release $50 \%$ of the $\mathrm{HC}$ above $200{ }^{\circ} \mathrm{C}$, and thus many DOCs would be able to oxidize the HCs upon their release. ZSM-5 and Ag/ZSM-5 have similar stability, but their T50s are 190 and $185^{\circ} \mathrm{C}$, respectively, and thus not as desirable as the BEA samples. The SSZ-13 zeolites not only store less HCs, but they release nearly all of the $\mathrm{HCs}$ by $150{ }^{\circ} \mathrm{C}$, and thus continue to show undesirable HCT properties.

\subsection{NO Storage}

As discussed above an ideal passive NOx adsorber (PNA) would have high storage below $200{ }^{\circ} \mathrm{C}$ and release NOx above $200{ }^{\circ} \mathrm{C}$ where a downstream SCR could be used in conjunction with ammonia from hydrolyzed urea. This hydrolysis occurs above $133^{\circ} \mathrm{C}$ [53], and the SCR reactivity typically reaches $90 \%$ by $180^{\circ} \mathrm{C}[54,55]$. The same systematic analysis procedure described above in the $\mathrm{HC}$ section was also used with NOx to understand how the evaluated samples meet the PNA criteria. Figure 4 shows a characteristic NOx storage and desorption profile; $\mathrm{Pd} / \mathrm{ZSM}-5$ is shown here, which is the same sample and experiment shown in Figure 2. Notably less NOx is adsorbed than HCs, but the adsorbed NOx is more strongly bound and releases at higher temperatures. Similar to THC, the uptake is divided into two sections, 3 (因) and 30 (国) minutes (Figure $4 \mathrm{~b}$ ), and the temperatures of $10 \%, 50 \%$ and $90 \%$ NOx release are determined (Figure $4 \mathrm{c}$ ). The data for all the samples are shown in Figure 5 with the specific values listed in Table 2. From these data two important observations are apparent. First, the Pd-zeolites are the only samples to have significant uptake, and second, only Pd/ZSM-5 and Pd/SSZ-13 maintains 50\% of the NOx above $150{ }^{\circ} \mathrm{C}$; in fact, over $50 \%$ of the NOx is still on Pd Pd/SSZ-13 at $224{ }^{\circ} \mathrm{C}$. This finding is consistent with other reports of Pd/SSZ-13 being one of the best PNAs [56,57] and that NO storage only occurs on ion-exchanged Pd sites [41]. Neither catalyst closed the NOx balance during release, suggesting there is some direct reduction in the stored NOx from HCs. This typically yields some $\mathrm{N}_{2} \mathrm{O}$ formation, but this reactor was not equipped with an analyzer that would allow $\mathrm{N}_{2} \mathrm{O}$ to be measured accurately. 


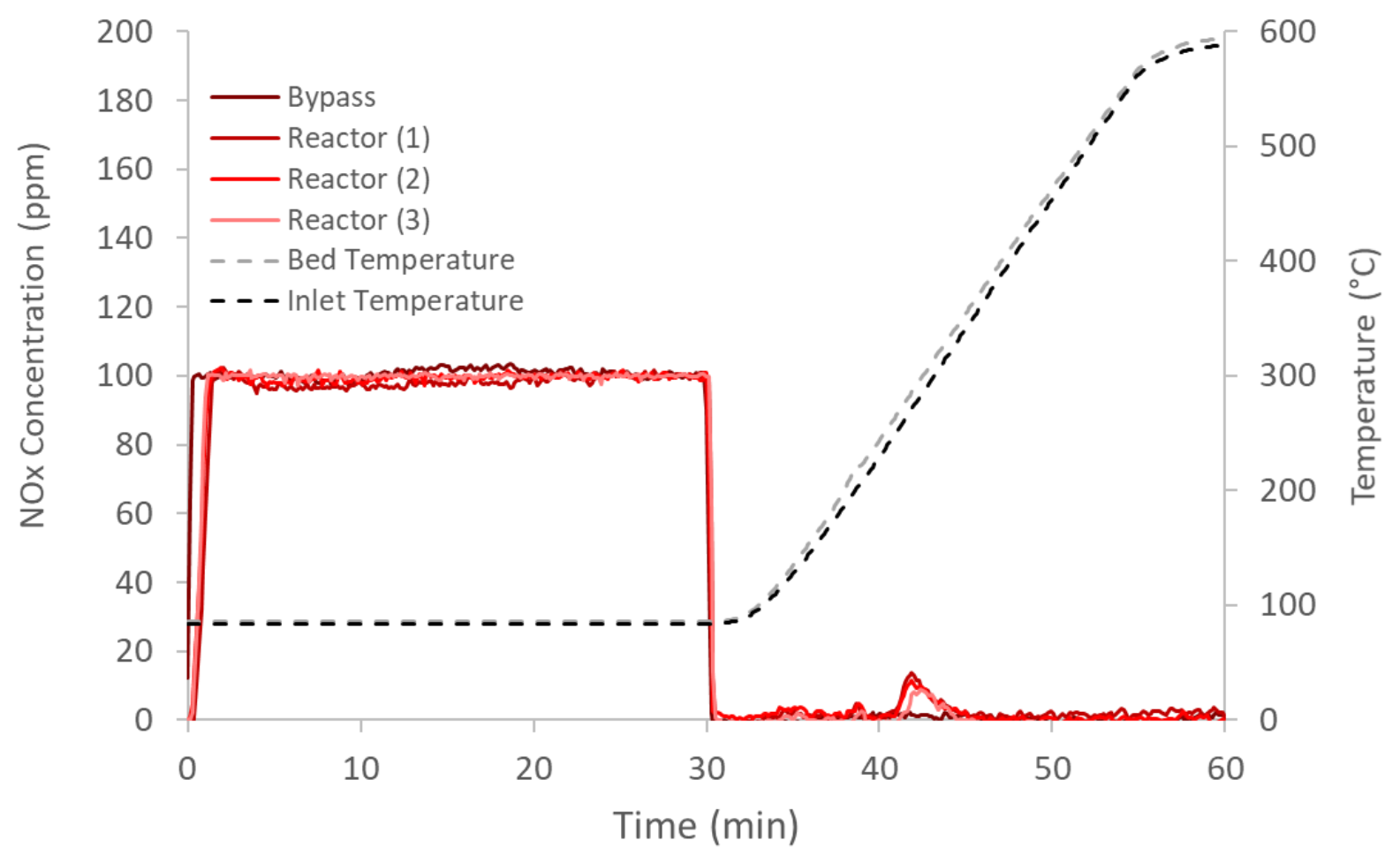

(a)

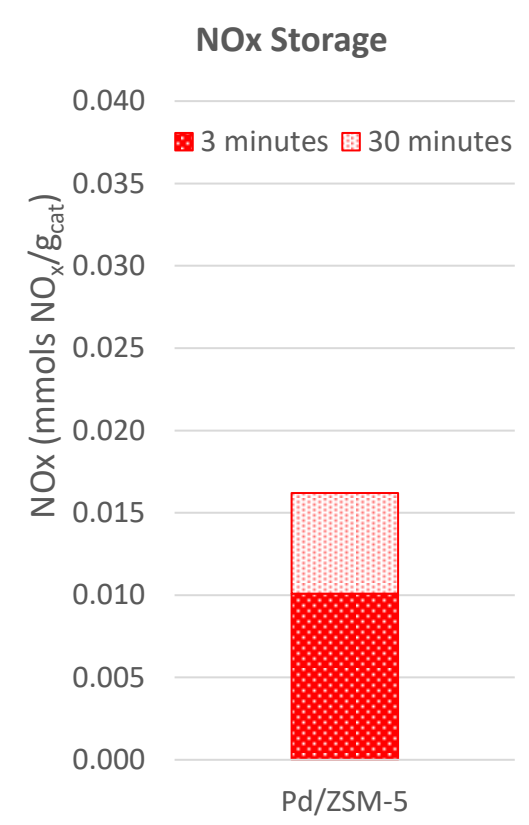

(b)
NOx Release Temp.

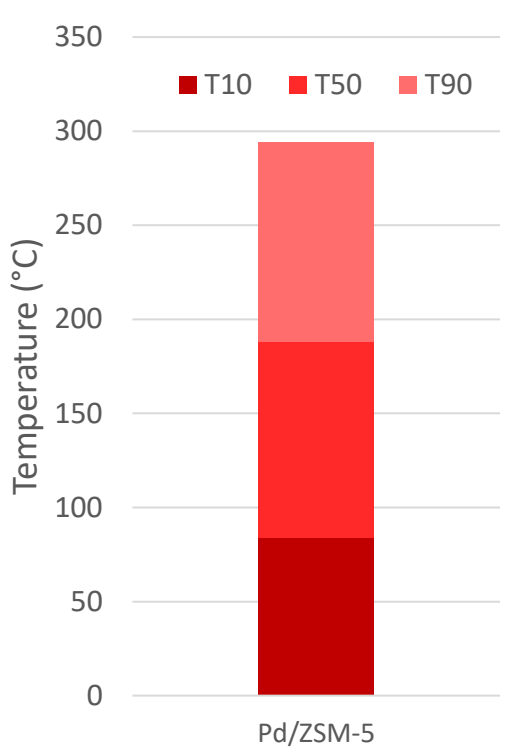

(c)

Figure 4. (a) NOx concentration for each of the three reactor evaluations throughout the 60 min experiment. (b) NOx

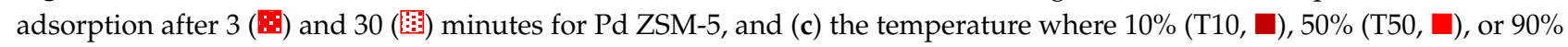
$(\mathrm{T} 90, \square)$ of the NOx is released for PD/ZSM-5. 


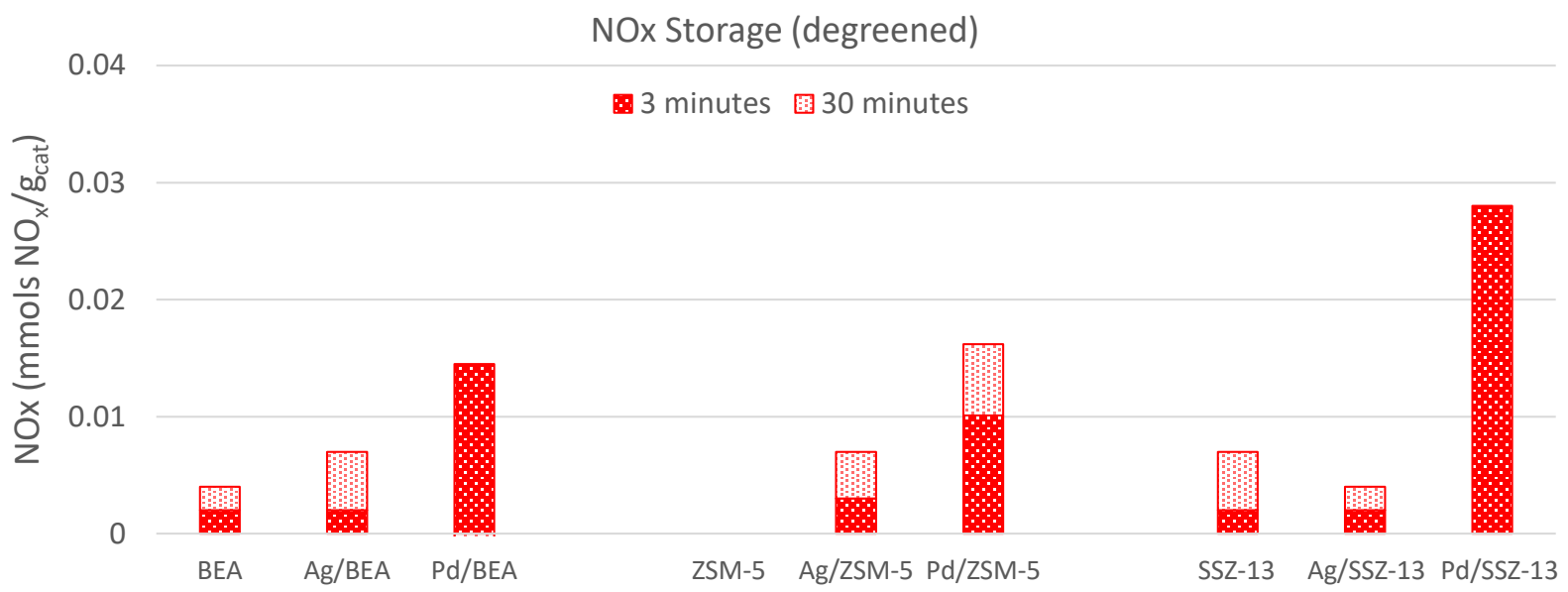

(a)

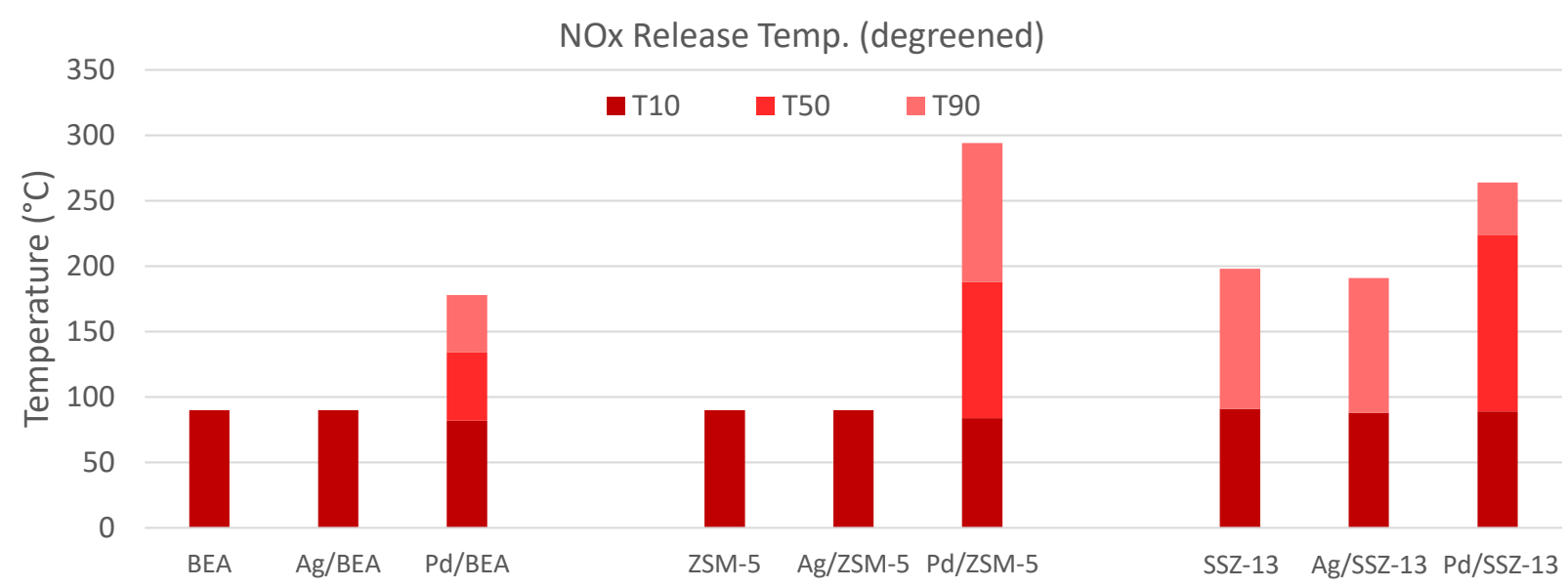

(b)

Figure 5. (a) NOx adsorption after 3 ( $10 \%(\mathrm{~T} 10, \mathbf{\square}), 50 \%(\mathrm{~T} 50, \mathbf{\square})$, or $90 \%(\mathrm{~T} 90, \mathbf{})$ of the NOx is released.

Table 2. NOx storage values ( $\mathrm{mmol} / \mathrm{g}_{\text {cat }}$ ) for ion-exchanged zeolites during lean trapping evaluation after 3 and $30 \mathrm{~min}$. The total amount of observed NOx released during the first $15 \mathrm{~min}$ of the ramp, and the temperature where $10 \%$ (T10), 50\% (T50), or 90\% (T90) of NOx is released is also shown.

\begin{tabular}{|c|c|c|c|c|c|c|}
\hline \multirow{3}{*}{$\begin{array}{l}\text { LTC-D (Storage) } \\
\text { Degreened Zeolite }\end{array}$} & \multirow{2}{*}{\multicolumn{2}{|c|}{ 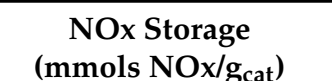 }} & \multirow{3}{*}{$\begin{array}{c}\text { NOx Release } \\
(\text { mmols NOx/g cat }) \\
15 \mathrm{~min}\end{array}$} & \multicolumn{3}{|c|}{ Release Temperature } \\
\hline & & & & \multirow{2}{*}{$\begin{array}{l}\mathrm{T} 10 \\
\left({ }^{\circ} \mathrm{C}\right)\end{array}$} & \multirow{2}{*}{$\begin{array}{l}\mathrm{T} 50 \\
\left({ }^{\circ} \mathrm{C}\right)\end{array}$} & \multirow{2}{*}{$\begin{array}{l}\text { T90 } \\
\left({ }^{\circ} \mathrm{C}\right)\end{array}$} \\
\hline & $3 \mathrm{~min}$ & $30 \mathrm{~min}$ & & & & \\
\hline BEA & 0.002 & 0.004 & 0.001 & 90 & 90 & 90 \\
\hline $\mathrm{Ag} / \mathrm{BEA}$ & 0.002 & 0.007 & 0.001 & 90 & 90 & 90 \\
\hline $\mathrm{Pd} / \mathrm{BEA}$ & 0.015 & 0.012 & 0.007 & 82 & 134 & 178 \\
\hline ZSM-5 & 0.000 & 0.000 & 0.000 & 90 & 90 & 90 \\
\hline $\mathrm{Ag} / \mathrm{ZSM}-5$ & 0.003 & 0.007 & 0.000 & 90 & 90 & 90 \\
\hline $\mathrm{Pd} / \mathrm{ZSM}-5$ & 0.010 & 0.016 & 0.007 & 84 & 188 & 294 \\
\hline SSZ-13 & 0.002 & 0.007 & 0.001 & 91 & 91 & 198 \\
\hline Ag/SSZ-13 & 0.002 & 0.004 & 0.002 & 88 & 88 & 191 \\
\hline Pd/SSZ-13 & 0.028 & 0.028 & 0.008 & 89 & 224 & 264 \\
\hline
\end{tabular}




\subsection{Hydrothermal Aging}

After fully evaluating all the samples, five of the most promising zeolites were hydrothermally aged to investigate their durability. BEA, Pd/BEA, ZSM-5, Pd/ZSM-5, and $\mathrm{Pd} / \mathrm{SSZ}-13$ were heated to $80{ }^{\circ} \mathrm{C}$ for $50 \mathrm{~h}$ and re-evaluated following the same protocols as before. Figure 6 shows the HC metrics for both storage and release with the values listed in Table 3. The amount of deactivation is minimal on storage, as the change is less than $10 \%$. The release temperatures for HCs are also similarly unchanged, as the T10s, T50s, and T90s are generally within a couple degrees of each other. The Pd/ZSM- 5 sample did result in a higher release temperature, as the T90 increased from 195 to $216^{\circ} \mathrm{C}$, suggesting its oxidation capability diminished after aging. This is supported by the closer match of storage and release quantities, 4.7 and 4.5 (mmols $\left.\mathrm{C}_{1} / \mathrm{g}_{\mathrm{cat}}\right)$. However, Pd/BEA maintained a large discrepancy in storage and release values as greater than $50 \%$ of the stored $\mathrm{HCs}$ are converted during release. In deciding which one of these samples would offer the best HCT functionality, it is clear that each of these hydrothermally aged samples would offer significant HCT capacity. The release profile of unexchanged BEA is slightly more favorable, since $\sim 50 \%$ of the stored HCs are released above $200{ }^{\circ} \mathrm{C}$, compared to $185^{\circ} \mathrm{C}$ for ZSM-5. If Pd is going to be used for HCTs, Pd/BEA offers significant durability, and although Pd does not aid in the storage capacity, its oxidation capability is valuable with the ability to oxidize over $50 \%$ of the stored HCs even after hydrothermal aging.

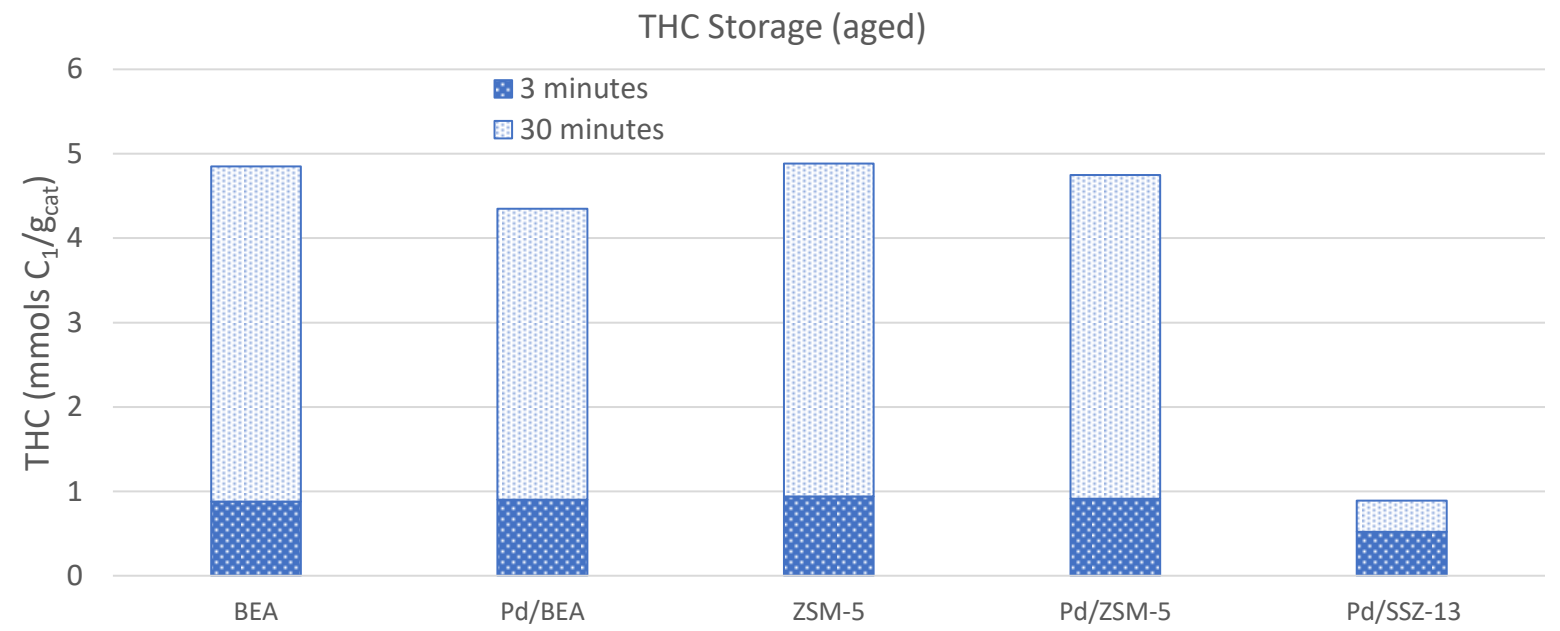

(a)

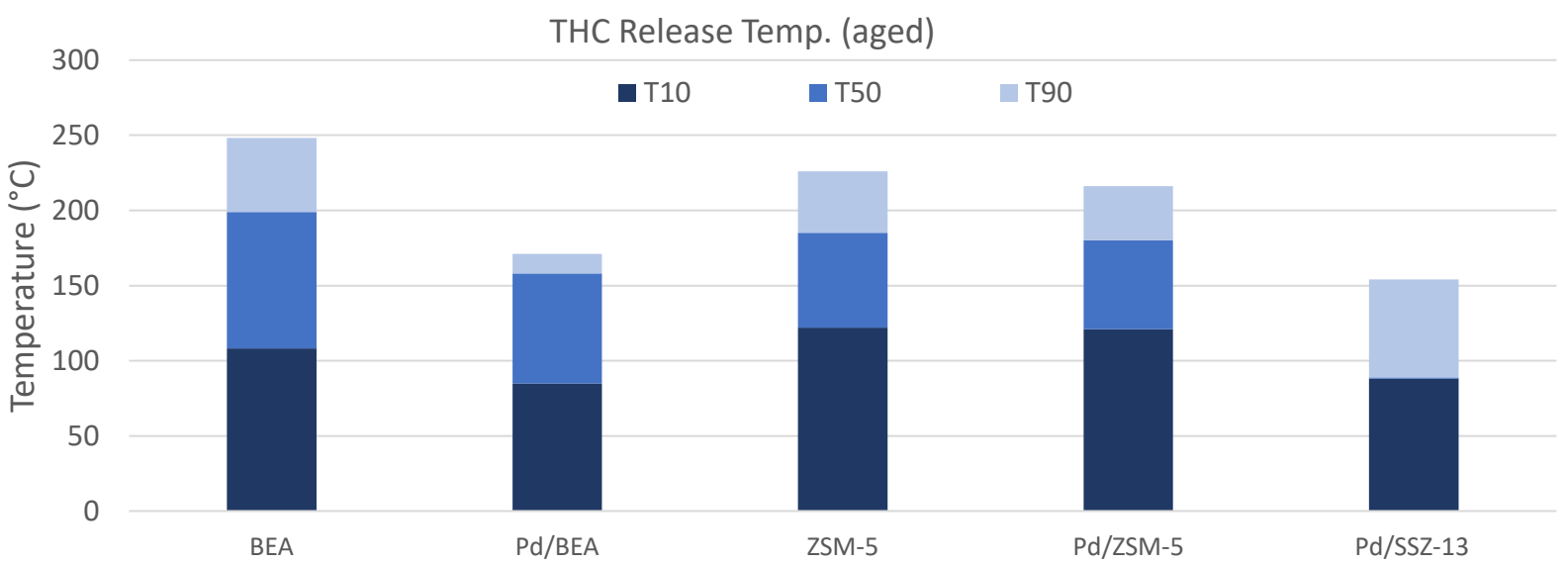

(b)

Figure 6. Following hydrothermal aging at $800{ }^{\circ} \mathrm{C}$ for $50 \mathrm{~h}$ (a) THC adsorption after 3 ( 30 ) and 30 (非) minutes for each of the materials studied, and (b) the temperature where 10\% (T10, $\square), 50 \%(\mathrm{~T} 50, \square)$, or $90 \%(\mathrm{~T} 90, \square)$ of THC is released. 
Table 3. THC storage values $\left(\mathrm{mmol} / \mathrm{g}_{\text {cat }}\right.$ ) for hydrothermally aged samples; THCs are reported on a $\mathrm{C}_{1}$ basis. The temperature where $10 \%$ (T10), 50\% (T50), or 90\% (T90) of THC is released is also shown.

\begin{tabular}{|c|c|c|c|c|c|c|}
\hline \multirow{3}{*}{$\begin{array}{l}\text { LTC-D (Storage) } \\
\text { Aged Zeolite }\end{array}$} & \multirow{2}{*}{\multicolumn{2}{|c|}{$\begin{array}{l}\text { NOx Storage } \\
\left(\mathrm{mmols} \mathrm{C}_{1} / \mathrm{g}_{\text {cat }}\right)\end{array}$}} & \multirow{3}{*}{$\begin{array}{c}\text { NOx Release } \\
\left.\text { (mmols } C_{1} / g_{\text {cat }}\right) \\
15 \mathrm{~min}\end{array}$} & \multicolumn{3}{|c|}{ Release Temperature } \\
\hline & & & & \multirow{2}{*}{$\begin{array}{l}\mathrm{T} 10 \\
\left({ }^{\circ} \mathrm{C}\right)\end{array}$} & \multirow{2}{*}{$\begin{array}{l}\mathrm{T} 50 \\
\left({ }^{\circ} \mathrm{C}\right)\end{array}$} & \multirow{2}{*}{$\begin{array}{l}\text { T90 } \\
\left({ }^{\circ} \mathrm{C}\right)\end{array}$} \\
\hline & $3 \mathrm{~min}$ & $30 \mathrm{~min}$ & & & & \\
\hline BEA & 0.9 & 4.8 & 4.9 & 108 & 199 & 248 \\
\hline $\mathrm{Pd} / \mathrm{BEA}$ & 0.9 & 4.3 & 2.1 & 85 & 158 & 171 \\
\hline ZSM-5 & 0.9 & 4.9 & 4.8 & 122 & 185 & 226 \\
\hline Pd/ZSM-5 & 0.9 & 4.7 & 4.5 & 121 & 180 & 216 \\
\hline $\mathrm{Pd} / \mathrm{SSZ}-13$ & 0.5 & 0.9 & 0.5 & 88 & 89 & 154 \\
\hline
\end{tabular}

The NOx storage behavior was notably different after hydrothermally aging. Figure 7 shows the NOx storage and release metrics for the five aged samples with the values shown in Table 4. From these results it is clear only the Pd/SSZ-13 maintains significant NOx storage capacity; in fact, both the storage capacity and release characteristics improve after aging. The storage increased from 0.028 to $0.036 \mathrm{mmols} \mathrm{NOx} / \mathrm{g}_{\mathrm{cat}}$, and the T50 increased from 224 to $262{ }^{\circ} \mathrm{C}$. Pd/BEA is the only other sample to show storage, but all of the NOx is released before $150^{\circ} \mathrm{C}$. All these results continue to reinforce that Pd/SSZ-13 is the only viable option for PNA amongst the samples studied here.

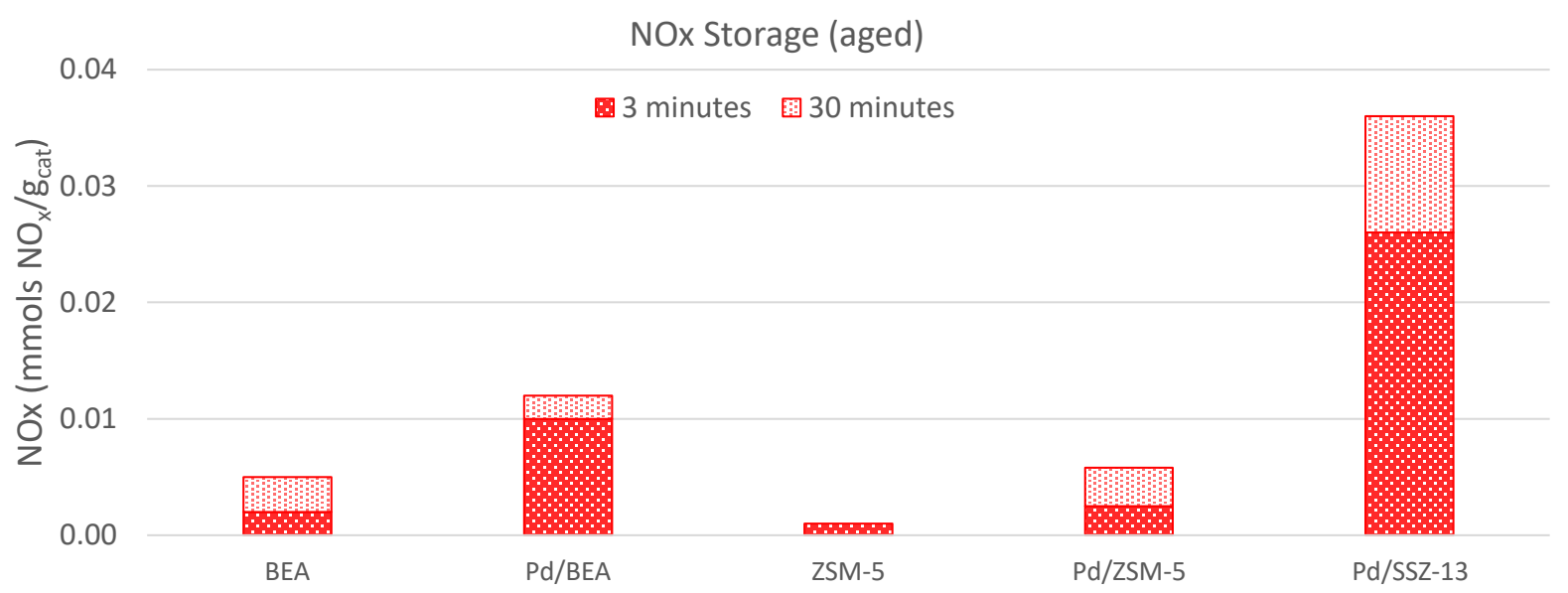

(a)

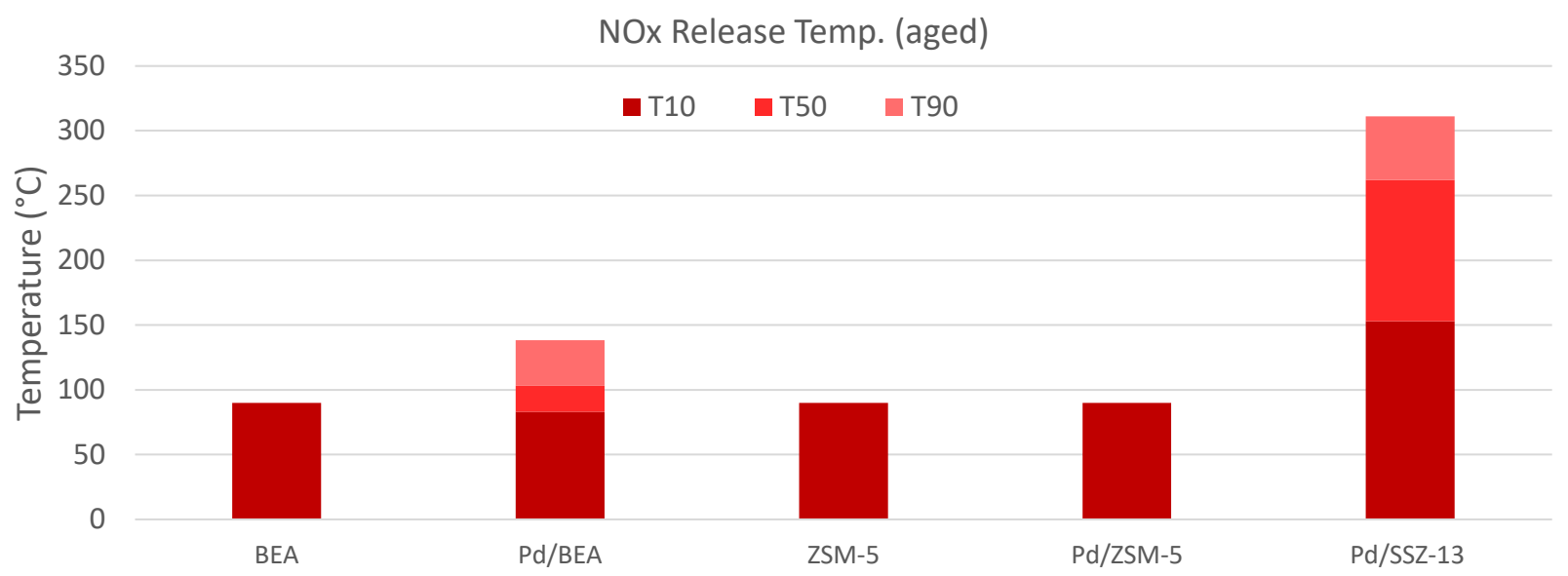

(b)

Figure 7. Following hydrothermal aging at $800{ }^{\circ} \mathrm{C}$ for $50 \mathrm{~h}$ (a) NOx adsorption after 3 ( 3 ) and 30 (㰓) minutes for each of the materials studied, and (b) the temperature where $10 \%(\mathrm{~T} 10, \square), 50 \%(\mathrm{~T} 50, \square)$, or $90 \%(\mathrm{~T} 90, \square)$ of the NOx is released. 
Table 4. NOx storage values (mmol/g $\mathrm{g}_{\text {cat }}$ ) for hydrothermally aged samples. The total amount of observed NOx released during the first $15 \mathrm{~min}$ of the ramp, and the temperature where $10 \%$ (T10), 50\% (T50), or 90\% (T90) of NOx is released is also shown.

\begin{tabular}{|c|c|c|c|c|c|c|}
\hline \multirow{3}{*}{$\begin{array}{c}\text { LTC-D (Storage) } \\
\text { Aged Zeolite }\end{array}$} & \multirow{2}{*}{\multicolumn{2}{|c|}{ 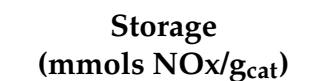 }} & \multirow{3}{*}{$\begin{array}{c}\text { Release } \\
\left(\mathrm{mmols} \mathrm{NOx} / \mathrm{g}_{\text {cat }}\right) \\
15 \mathrm{~min}\end{array}$} & \multicolumn{3}{|c|}{ Release Temperature } \\
\hline & & & & \multirow{2}{*}{$\begin{array}{l}\mathrm{T} 10 \\
\left({ }^{\circ} \mathrm{C}\right)\end{array}$} & \multirow{2}{*}{$\begin{array}{l}\mathrm{T} 50 \\
\left({ }^{\circ} \mathrm{C}\right)\end{array}$} & \multirow{2}{*}{$\begin{array}{l}\mathrm{T} 90 \\
\left({ }^{\circ} \mathrm{C}\right)\end{array}$} \\
\hline & $3 \mathrm{~min}$ & $30 \mathrm{~min}$ & & & & \\
\hline BEA & 0.002 & 0.005 & 0.002 & 90 & 90 & 90 \\
\hline $\mathrm{Pd} / \mathrm{BEA}$ & 0.010 & 0.012 & 0.004 & 83 & 103 & 138 \\
\hline ZSM-5 & 0.001 & 0.001 & 0.000 & 90 & 90 & 90 \\
\hline Pd/ZSM-5 & 0.003 & 0.006 & 0.000 & 90 & 90 & 90 \\
\hline Pd/SSZ-13 & 0.026 & 0.036 & 0.021 & 153 & 262 & 311 \\
\hline
\end{tabular}

\section{Experimental}

\subsection{Synthesis of Ion-Exchanged Zeolites}

The traps studied here were synthesized by ion-exchange as reported previously [40]. Briefly, commercial BEA (CP814E)-Si / $\mathrm{Al}=12.5$ and ZSM-5 (CBV 3024E)-Si $/ \mathrm{Al}=15$ zeolites were ion-exchanged with $75 \mathrm{~mL}$ of a $0.2 \mathrm{M} \mathrm{AgNO}_{3}$ and $51 \mathrm{~mL}$ of a $9.4 \mathrm{mM} \mathrm{Pd}\left(\mathrm{NH}_{3}\right)_{4}\left(\mathrm{NO}_{3}\right)_{2}$ stock solution at $60{ }^{\circ} \mathrm{C}$ and $80^{\circ} \mathrm{C}$ for $24 \mathrm{~h}$, respectively. Prior to ion-exchange the $\mathrm{NH}_{4}$-form zeolites (as purchased from Zeolyst) were converted to their H-form by calcination at $500{ }^{\circ} \mathrm{C}$ for $2 \mathrm{~h}$ in static air. Single ionic exchange of $\mathrm{Ag}$ and Pd with BEA and ZSM- 5 zeolites led to the synthesis of $1 \mathrm{wt} . \% \mathrm{Ag} / \mathrm{BEA}, 1 \mathrm{wt} . \% \mathrm{Ag} / \mathrm{ZSM}-5,1 \mathrm{wt} . \%$ Pd/BEA and $1 \mathrm{wt} . \%$ $\mathrm{Pd} / \mathrm{ZSM}-5$ catalysts. The samples were filtered, washed with DI water, dried at $100{ }^{\circ} \mathrm{C}$ for $8 \mathrm{~h}$ and calcined in air at $500{ }^{\circ} \mathrm{C}$ for $2 \mathrm{~h}$ before further evaluation. For Pd/SSZ-13, an aqueous solution of $\mathrm{Pd}\left(\mathrm{NO}_{3}\right)_{2} \cdot 2 \mathrm{H}_{2} \mathrm{O}(0.037 \mathrm{mM}, 10 \mathrm{~mL})$ was added dropwise to the $\mathrm{NH}_{4}$-SSZ-13-Si / $\mathrm{Al}=15$ suspension ( $3.960 \mathrm{~g}$ in $50 \mathrm{~mL}$ water; $250 \mathrm{RPM}$ stirring) at $80^{\circ} \mathrm{C}$ for $20 \mathrm{~h}$. Filtered powder was calcined in air at $500{ }^{\circ} \mathrm{C}$ for $5 \mathrm{~h}$. All samples were pelletized to $250-500 \mu \mathrm{m}$ prior to evaluation. ICP was performed on several of the metal-exchanged materials in this study, and the metal loadings ranged from $0.97-1.07 \mathrm{wt} . \%$, which is in good agreement with the expected value of $1 \mathrm{wt} . \%$.

\subsection{Trapping Characterization}

Characterization of HC and NOx trapping was conducted utilizing a storage protocol developed by the U.S. DRIVE Advanced Combustion and Emissions Control Technical Team [38,39]. Quartz wool and $100 \mathrm{mg}$ of trapping material were loaded into an $8 \mathrm{~mm}$ diameter quartz reactor U-tube to create a plug-flow bed with one K-type thermocouple placed at the center of the bed and another K-type thermocouple approximately $1 \mathrm{~cm}$ above the bed to record bed and inlet temperatures, respectively. A visual description of the storage and release characterization is given in Figure 8. All materials were degreened in $\left[\mathrm{O}_{2}\right]=12 \%,\left[\mathrm{CO}_{2}\right]=6 \%$, and $\left[\mathrm{H}_{2} \mathrm{O}\right]=6 \%$ with Ar balance for $4 \mathrm{~h}$ at $700^{\circ} \mathrm{C}$ prior to evaluation and the gas flow was normalized to $200 \mathrm{~L} \cdot \mathrm{g}^{-1} \mathrm{~h}^{-1}$. Water was introduced into the system via a bubbler set to $50.6^{\circ} \mathrm{C}$ with heated lines to maintain vapor phase. Decane and toluene were introduced to the reactor similarly via a bubbler at $5{ }^{\circ} \mathrm{C}$. Instrument response time baselines were determined through the reactor bypass by introduction of reactant gasses for $30 \mathrm{~min}$ via a 4 -way switching valve. NOx concentrations were determined by NOx chemiluminescence analyzer (CLD $822 \mathrm{CM}$ hr; Ecophysics, Dürnten, Switzerland) and the THC concentrations were determined by FID (flame ionization detector, California Analytical HFID-700, Orange, CA, USA) and reported on a $C_{1}$ basis. As needed, individual HC species were determined by mass spectrometer (Stanford Research Systems RGA 100, Sunnyvale, CA, USA) using $\mathrm{m} / \mathrm{z}=26,57$, and 91 for ethylene $\left(\mathrm{C}_{2} \mathrm{H}_{4}\right)$, decane $\left(\mathrm{C}_{10} \mathrm{H}_{22}\right)$, and toluene $\left(\mathrm{C}_{7} \mathrm{H}_{8}\right)$, respectively. 


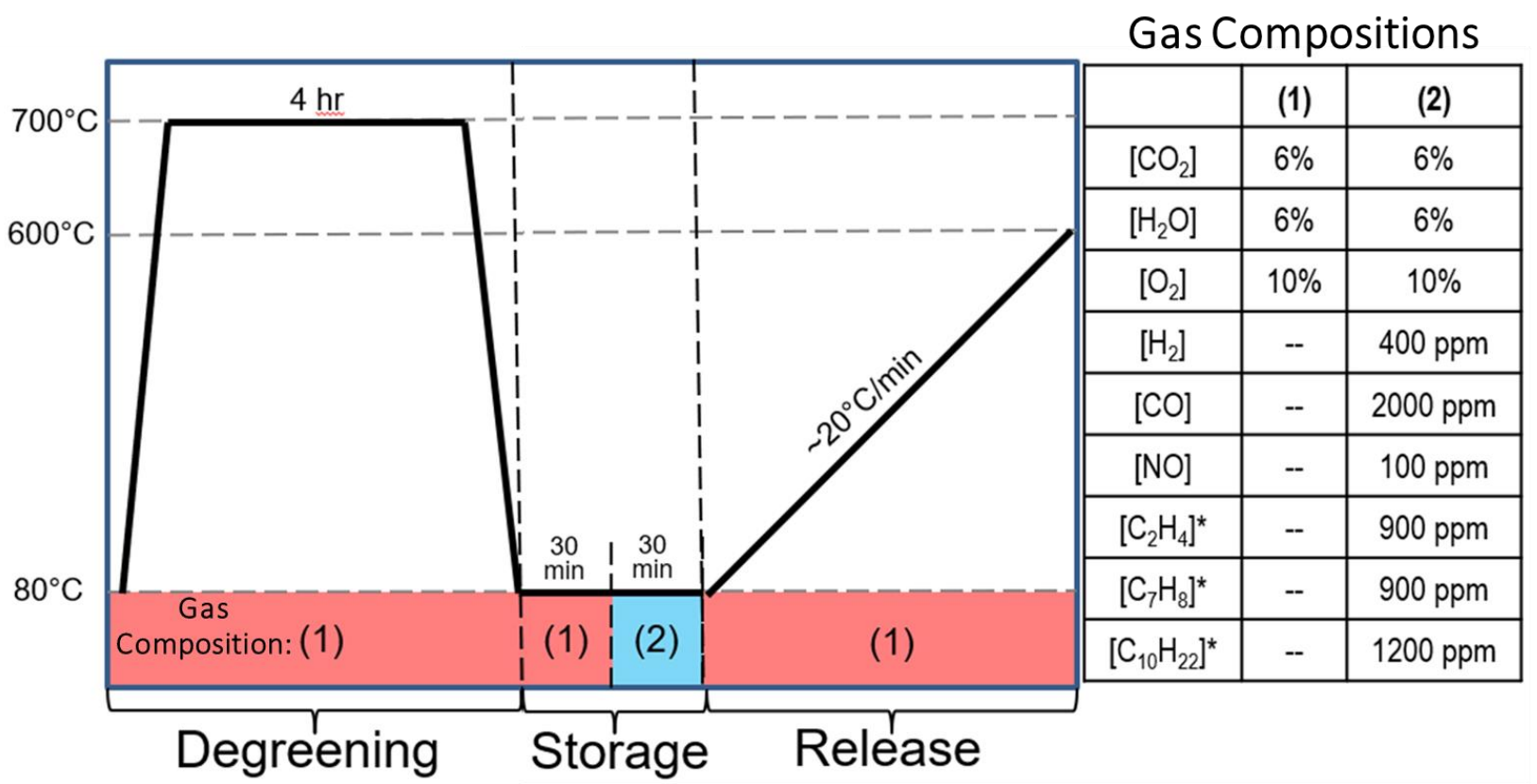

Figure 8. Storage and release characterization protocol (left) and gas concentrations (right). * — hydrocarbons are listed on a $\mathrm{C}_{1}$ basis.

Storage and release were characterized sequentially by $30 \mathrm{~min}$ exposure of reactant gasses at $80{ }^{\circ} \mathrm{C}$ after which the temperature was ramped at $20^{\circ} \mathrm{C} / \mathrm{min}$ to a maximum temperature of $600{ }^{\circ} \mathrm{C}$ in the presence of the $\mathrm{O}_{2}, \mathrm{CO}_{2}$, and $\mathrm{H}_{2} \mathrm{O}$ (Ar balance). Calculation of total reactant storage values and efficiencies were accomplished by subtraction of measured reactor outlet gas concentrations from the baseline, beginning and ending with the moment of valve switching. It should be noted the baseline is measured in the bypass line of the reactor. Release values were calculated by a similar comparison of baseline and reactor values during the $26 \mathrm{~min}$ temperature ramp and efficiencies are reported as a percentage of reactant stored. This storage/release procedure was repeated 3 times for each sample and then averaged.

Following the degreened evaluations of the samples, the most promising materials were hydrothermally aged at $800{ }^{\circ} \mathrm{C}$ for $50 \mathrm{~h}$ in $\left[\mathrm{O}_{2}\right]=12 \%$, $\left[\mathrm{CO}_{2}\right]=6 \%$, and $\left[\mathrm{H}_{2} \mathrm{O}\right]=6 \%$ with Ar balance. These samples were then re-evaluated according to the procedure outlined above. According to the low-temperature storage protocol [38,39], this time and temperature is intended to stress the materials to a similar level that would be expected at the end of their full-useful-life.

\section{Conclusions}

Overall, these samples show significant capability to perform both HCT and PNA functionalities. The presence of $\mathrm{Ag}$ or Pd does not universally result in increased HC storage, but $\mathrm{Pd}$ and its excellent oxidation reactivity aids in the conversion of the released HCs directly on the HCT. The pores of SSZ-13 are too small to store significant quantities of HCs, and thus BEA and ZSM- 5 are preferred for HCTs. Pd is crucial for the adsorption of NOx, and under these gas mixtures, $\mathrm{Pd} / \mathrm{SSZ}-13$ provides the best storage and release characteristics. Hydrothermal aging largely supports these results with minimal storage losses observed for BEA, Pd/BEA, ZSM-5, Pd/ZSM-5, and Pd/SSZ-13. Only Pd/BEA maintained its $\mathrm{HC}$ oxidation reactivity after aging. Pd/SSZ-13 is clearly the only sample evaluated to illustrate reasonable PNA behavior after aging, and in fact its storage capacity increased while its release temperature showed improved characteristics with greater than $50 \%$ of the stored NOx being released above $250{ }^{\circ} \mathrm{C}$. 
Author Contributions: Conceptualization, T.J.T.; Data curation, T.J.T., A.J.B., P.K. and E.A.K.; Formal analysis, T.J.T. and J.-S.C.; Funding acquisition, T.J.T.; Investigation, T.J.T.; Methodology, T.J.T.; Project administration, T.J.T.; Supervision, T.J.T.; Writing-original draft, T.J.T. and A.J.B.; Writing-review and editing, T.J.T., P.K., E.A.K. and J.-S.C. All authors have read and agreed to the published version of the manuscript.

Funding: Funding for this work was provided by the U.S. Department of Energy's Vehicle Technologies Office (VTO). The authors greatly appreciate support from Ken Howden, Siddiq Khan, and Gurpreet Singh at VTO.

Data Availability Statement: The data presented in this study are available on request from the corresponding author.

Acknowledgments: This manuscript has been authored by UT-Battelle, LLC, under Contract No. DE-AC0500OR22725 with the U.S. Department of Energy. The publisher, by accepting the article for publication, acknowledges that the United States Government retains a non-exclusive, paid-up, irrevocable, worldwide license to publish or reproduce the published form of this manuscript, or allow others to do so, for the United States Government purposes. The Department of Energy will provide public access to these results of federally sponsored research in accordance with the DOE Public Access Plan (http:/ / energy.gov/downloads/doe-public-access-plan, accessed on 29 March 2021).

Conflicts of Interest: The authors declare no conflict of interest.

\section{References}

1. Dürnholz, M.; Eifler, G.; Endres, H. Exhaust-Gas Recirculation-A Measure to Reduce Exhaust Emissions of DI Diesel Engines; No. 920725; SAE Technical Paper; SAE International: Warrendale, PA, USA, 1992. [CrossRef]

2. Johnson, T.V. Review of Diesel Emissions and Control. Int. J. Engine Res. 2009, 10, 275-285. [CrossRef]

3. Kyriakidou, E.A.; Toops, T.J.; Choi, J.-S.; Lance, M.J.; Parks, J.E., II. Exhaust Treatment Catalysts with Enhanced Hydrothermal Stability and Low-Temperature Activity. U.S. Patent 10,427,137 B2, 1 October 2019.

4. Wong, A.P.; Kyriakidou, E.A.; Toops, T.J.; Regalbuto, J.R. The Catalytic Behavior of Precisely Synthesized Pt-Pd Bimetallic Catalysts for Use as Diesel Oxidation Catalysts. Catal. Today 2016, 267, 145-156. [CrossRef]

5. Kim, M.-Y.; Kyriakidou, E.A.; Choi, J.-S.; Toops, T.J.; Binder, A.J.; Thomas, C.; Parks, J.E., II; Schwartz, V.; Chen, J.; Hensley, D.K.

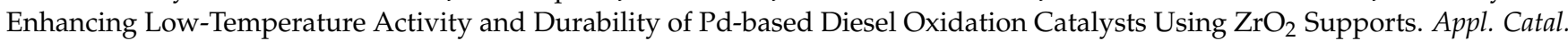
B Environ. 2016, 187, 181-194. [CrossRef]

6. Hoang, S.; Guo, Y.; Binder, A.; Tang, W.; Wang, S.; Liu, J.; Huan, T.; Lu, X.; Wang, Y.; Ding, Y.; et al. Activating Low-Temperature Diesel Oxidation by Single-Atom Pt on $\mathrm{TiO}_{2}$ Nanowire Array. Nat. Commun. 2020, 11, 1-10.

7. Wang, A.; Olsson, L. The Impact of Automotive Catalysis on the United Nations Sustainable Development Goals. Nat. Catal. 2019, 2, 566-570. [CrossRef]

8. Johnson, T.V. Diesel Emissions in Review. SAE Int. J. Engines 2011, 4, 143-157. [CrossRef]

9. Zelinsky, R.; Epling, W. Effects of Multicomponent Hydrocarbon Feed on Hydrocarbon Adsorption-Desorption and Oxidation Light-Off Behavior on a Pd/BEA Hydrocarbon Trap. Catal. Lett. 2019, 149, 3194-3202. [CrossRef]

10. Beale, A.M.; Gao, F.; Lezcano-Gonzalez, I.; Peden, C.H.F.; Szanyi, J. Recent Advances in Automotive Catalysis for NOx Emission Control by Small-Pore Microporous Materials. Chem. Soc. Rev. 2015, 44, 7371-7405. [CrossRef]

11. Naseri, M.; Aydin, C.; Mulla, S.; Conway, R.; Chatterjee, S. Development of Emission Control Systems to Enable High NOx Conversion on Heavy Duty Diesel Engines. SAE Int. J. Engines 2015, 8, 1144-1151. [CrossRef]

12. Squaiella, L.L.F.; Martins, C.A.; Pedro, T.L. Strategies for Emission Control in Diesel Engine to Meet Euro VI. Fuel 2013, 104, 183-193. [CrossRef]

13. Lao, C.T.; Akroyd, J.; Eaves, N.; Smith, A.; Morgan, N.; Nurkowski, D.; Bhave, A.; Kraft, M. Investigation of the Impact of the Configuration of Exhaust After-Treatment System for Diesel Engines. Appl. Energy 2020, 267, 114844. [CrossRef]

14. Lyu, M.; Bao, X.; Zhu, R.; Matthews, R. State-of-the-Art Outlook for Light-Duty Vehicle Emission Control Standards and Technologies in China. Clean Technol. Environ. Policy 2020, 22, 757-771. [CrossRef]

15. Weilenmann, M.; Favez, J.-Y.Y.; Alvarez, R. Cold-Start Emissions of Modern Passenger Cars at Different Low Ambient Temperatures and Their Evolution over Vehicle Legislation Categories. Atmos. Environ. 2009, 43, 2419-2429. [CrossRef]

16. Iliyas, A.; Zahedi-Niaki, M.H.; Eić, M.; Kaliaguine, S. Control of Hydrocarbon Cold-Start Emissions: A Search for Potential Adsorbents. Microporous Mesoporous Mater. 2007, 102, 171-177. [CrossRef]

17. Lee, J.; Theis, J.R.; Kyriakidou, E.A. Vehicle Emissions Trapping Materials: Successes, Challenges, and the Path Forward. Appl. Catal. B Environ. 2019, 243, 397-414. [CrossRef]

18. Curran, S.; Prikhodko, V.; Cho, K.; Sluder, C.S.; Parks, J.; Wagner, R.; Kokjohn, S.; Reitz, R.D. In-Cylinder Fuel Blending of Gasoline/Diesel for Improved Efficiency and Lowest Possible Emissions on a Multi-Cylinder Light-Duty Diesel Engine; No. 2010-01-2206; SAE Technical Paper; SAE International: Warrendale, PA, USA, 2010. 
19. Zheng, M.; Asad, U.; Graham, T.; Reader, Y.T.; Wang, M. Energy Efficiency Improvement Strategies for a Diesel Engine in Low-Temperature Combustion. Int. J. Energy Res. 2009, 33, 8-28. [CrossRef]

20. Zammit, M.; DiMaggio, C.; Kim, C.; Lambert, C.; Muntean, G.; Peden, C.; Parks, J.; Howden, K. Future Automotive Aftertreatment Solutions: The $150{ }^{\circ} \mathrm{C}$ Challenge Workshop Report. Available online: https://cleers.org/wp-content/uploads/2012_The_150C_ Challenge_Workshop_Report.pdf (accessed on 29 March 2021).

21. Environmental Protection Agency, U.S. EPA-420-F-13-016a; U. S. Environmental Protection Agency: Washington, DC, USA, 2013; pp. 1-4.

22. Environmental Protection Agency, U.S.; Department of Transportation, National Highway Traffic Safety Administration. 2017 and Later Model Year Light-Duty Vehicle Greenhouse Gas Emissions and Corporate Average Fuel Economy Standards. Fed. Regist. 2012, 77, 62623-63200.

23. Sarshar, Z.; Zahedi-Niaki, M.H.; Huang, Q.; Eić, M.; Kaliaguine, S. MTW Zeolites for Reducing Cold-Start Emissions of Automotive Exhaust. Appl. Catal. B Environ. 2009, 87,37-45. [CrossRef]

24. Burke, N.R.; Trimm, D.L.; Howe, R.F. The Effect of Silica:Alumina Ratio and Hydrothermal Ageing on the Adsorption Characteristics of BEA Zeolites for Cold Start Emission Control. Appl. Catal. B Environ. 2003, 46, 97-104. [CrossRef]

25. Huuhtanen, M.; Rahkamaa-Tolonen, K.; Maunula, T.; Keiski, R.L. Pt-Loaded Zeolites for Reducing Exhaust Gas Emissions at Low Temperatures and in Lean Conditions. Catal. Today 2005, 100, 321-325. [CrossRef]

26. López, J.M.; Navarro, M.V.; García, T.; Murillo, R.; Mastral, A.M.; Varela-Gandía, F.J.; Lozano-Castelló, D.; Bueno-López, A.; Cazorla-Amorós, D. Screening of Different Zeolites and Silicoaluminophosphates for the Retention of Propene Under Cold Start Conditions. Microporous Mesoporous Mater. 2010, 130, 239-247. [CrossRef]

27. Kim, D.J.; Kim, J.W.; Yie, J.E.; Moon, H. Temperature-Programmed Adsorption and Characteristics of Honeycomb Hydrocarbon Adsorbers. Ind. Eng. Chem. Res. 2002, 41, 6589-6592. [CrossRef]

28. Kim, H.; Jang, E.; Jeong, Y.; Kim, J.; Kang, C.Y.; Kim, C.H.; Baik, H.; Lee, K.-Y.; Choi, J. On the Synthesis of a HierarchicallyStructured ZSM-5 Zeolite and the Effect of its Physicochemical Properties with Cu Impregnation on Cold-Start Hydrocarbon Trap Performance. Catal. Today 2018, 314, 78-93. [CrossRef]

29. Westermann, A.; Azambre, B.; Chebbi, M.; Koch, A. Modification of Y Faujasite Zeolites for the Trapping and Elimination of a Propene-Toluene-Decane Mixture in the Context of Cold-Start. Microporous Mesoporous Mater. 2016, 230, 76-88. [CrossRef]

30. Azambre, B.; Westermann, A.; Finqueneisel, G.; Can, F.; Comparot, J.D. Adsorption and Desorption of a Model Hydrocarbon Mixture Over HY Zeolite under Dry and Wet Conditions. J. Phys. Chem. C 2015, 119, 315-331. [CrossRef]

31. Zheng, Y.; Kovarik, L.; Mark, H.; Engelhard, Y.W.; Wang, Y.; Gao, F.; Szanyi, J. Low-Temperature Pd/Zeolite Passive NOx Adsorbers: Structure, Performance, and Adsorption Chemistry. J. Phys. Chem. C 2017, 121, 15793-15803. [CrossRef]

32. Yu, Q.; Chen, X.; Bhat, A.; Tang, X.; Yi, H.; Lin, X.; Schwank, J.W. Activation of Passive NOx Adsorbers by Pretreatment with Reaction Gas Mixture. Chem. Eng. J. 2020, 399, 125727. [CrossRef]

33. Ryou, Y.; Lee, J.; Lee, H.; Kim, C.H.; Kim, D.H. Effect of Various Activation Conditions on the Low Temperature NO Adsorption Performance of Pd/SSZ-13 Passive NOx Adsorber. Catal. Today 2019, 320, 175-180. [CrossRef]

34. Malamis, S.A.; Harold, M.P.; Epling, W.S. Coupled NO and C3H6 Trapping, Release and Conversion on Pd/BEA: Evaluation of the Lean Hydrocarbon NOx Trap. Ind. Eng. Chem. Res. 2019, 58, 22912-22923. [CrossRef]

35. Chen, H.-Y.; Mulla, S.; Weigert, E.; Camm, K.; Ballinger, T.; Cox, J.; Blakeman, P. Old Start Concept (CSCTM): A Novel Catalyst for Cold Start Emission Control. SAE Int. J. Fuels Lubr. 2013, 6, 372-381. [CrossRef]

36. Lupescu, J.; Chanko, T.; Richert, J.; DeVries, J. Treatment of Vehicle Emissions from the Combustion of E85 and Gasoline with Catalyzed Hydrocarbon Traps. SAE Int. J. Fuels Lubr. 2009, 2, 485-496. [CrossRef]

37. Nunan, J.; Lupescu, J.; Denison, G.; Ball, D.; Moser, D. HC Traps for Gasoline and Ethanol Applications. SAE Int. J. Fuels Lubr. 2013, 6, 430-449. [CrossRef]

38. Aftertreatment Protocols for Catalyst Characterization and Performance Evaluation: Low-Temperature Storage Catalyst Test Protocol. Available online: https:/ / cleers.org/wp-content/uploads/2018/03/2018_LTAT_Low-Temperature-Storage-Protocol. pdf (accessed on 29 March 2021).

39. Kenneth, G.; Rappé, C.D.; Josh, A.; Pihl, J.R.; Theis, S.; Oh, H.; Galen, B.; Fisher, J.P.; Vencon, G.; Easterling, M.Y.; et al. Aftertreatment Protocols for Catalyst Characterization and Performance Evaluation: Low-Temperature Oxidation, Storage, Three-Way, and $\mathrm{NH}_{3}$-SCR Catalyst Test Protocols. Emiss. Control Sci. Technol. 2019, 5, 183-214. [CrossRef]

40. Kyriakidou, E.A.; Lee, J.; Choi, J.-S.; Lance, M.; Toops, T.J. A Comparative Study of Silver- and Palladium-Exchanged Zeolites in Propylene and Nitrogen Oxide Adsorption and Desorption for Cold-Start Applications. Catal. Today 2020. [CrossRef]

41. Chen, H.-Y.; Collier, J.E.; Liu, D.; Mantarosie, L.; Durán-Martín, D.; Novák, V.; Rajaram, R.R.; Tompsett, D. Low Temperature NO Storage of Zeolite Supported Pd for Low Temperature Diesel Engine Emission Control. Catal. Lett. 2016, 146, $1706-1711$. [CrossRef]

42. Westermann, A.; Azambre, B.; Finqueneisel, G.; Da Costa, P.; Can, F. Evolution of Unburnt Hydrocarbons Under 'Cold-Start' Conditions from Adsorption/Desorption to Conversion: On the Screening of Zeolitic Materials. Appl. Catal. B 2014, 158-159, 48-59. [CrossRef]

43. Kang, S.B.; Kalamaras, C.; Balakotaiah, V.; Epling, W. Hydrocarbon Trapping over Ag-Beta Zeolite for Cold-Start Emission Control. Catal. Lett. 2017, 147, 1355-1362. [CrossRef] 
44. Khivantsev, K.; Jaegers, N.R.; Kovarik, L.; Hanson, J.C.; Tao, F.; Tang, Y.; Zhang, X.; Koleva, I.Z.; Aleksandrov, H.A.; Vayssilov, G.N.; et al. Achieving Atomic Dispersion of Highly Loaded Transition Metals in Small-Pore Zeolite SSZ-13: High-Capacity and High Efficiency Low Temperature CO and Passive NOx Adsorbers. Angew. Chem. 2018, 57, 16672-16677. [CrossRef]

45. Ryou, Y.; Lee, J.; Cho, S.J.; Lee, H.; Kim, C.H.; Kim, D.H. Activation of Pd/SSZ-13 Catalyst by Hydrothermal Aging Treatment in Passive NO Adsorption Performance at Low Temperature for Cold Start Application. Appl. Catal. B 2017, 212, 140-149. [CrossRef]

46. Lee, J.; Ryou, Y.S.; Hwang, S.; Kim, Y.; Cho, S.J.; Lee, H.; Kim, C.H.; Kim, D.H. Comparative Study of the Mobility of Pd Species in SSZ-13 and ZSM-5, and its Implication for their Activity as Passive NOx Adsorber (PNAs) after Hydro-Thermal Aging. Catal. Sci. Technol. 2019, 9, 163-173. [CrossRef]

47. Ball, D.; Zammit, M.; Wuttke, J.; Buitrago, C. Investigation of LEV-III Aftertreatment Designs. SAE Int. J. Fuels Lubr. 2011, 4, 1-8. [CrossRef]

48. Gao, Z.; Kim, M.-Y.; Choi, J.-S.; Daw, C.S.; Parks, J.E., II; Smith, D.E. Cold-Start Emissions Control in Hybrid Vehicles Equipped with a Passive Adsorber for Hydrocarbons and Nitrogen Oxides. J. Automob. Eng. 2012, 226, 1396-1407. [CrossRef]

49. McLeary, E.E.; Jansen, J.C.; Kapteijn, F. Zeolite Based Films, Membranes and Membrane Reactors: Progress and Prospects. Microporous Mesoporous Mater. 2006, 90, 198-220. [CrossRef]

50. Li, Y.; Li, L.; Yu, J. Applications of Zeolites in Sustainable Chemistry. Chem 2017, 3, 928-949. [CrossRef]

51. Jonsson, R.; Woo, J.; Skoglundh, M.; Olsson, L. Zeolite Beta Doped with La, Fe, and Pd as a Hydrocarbon Trap. Catalysts 2020, 10, 173. [CrossRef]

52. Park, J.H.; Park, S.J.; Ahn, H.A.; Nam, I.S.; Yeo, G.K.; Kil, J.K.; Youn, Y.K. Promising Zeolite-Type Hydrocarbon Trap Catalyst by a Knowledge-Based Combinatorial Approach. Microporous Mesoporous Mater. 2009, 117, 178-184. [CrossRef]

53. Schaber, P.M.; Colson, J.; Higgins, S.; Thielen, D.; Anspach, B.; Brauer, J. Thermal Decomposition (Pyrolysis) of Urea in an Open Reaction Vessel. Thermochim. Acta 2004, 424, 131-142. [CrossRef]

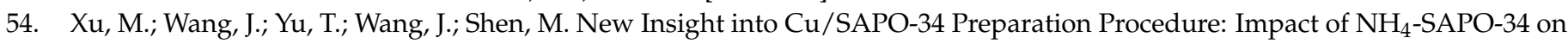
the Structure and $\mathrm{Cu}$ Distribution in Cu-SAPO-34 NH${ }_{3}$-SCR Catalysts. Appl. Catal. B Environ. 2018, 220, 161-170. [CrossRef]

55. Rahkamaa-Tolonen, K.; Maunula, T.; Lomma, M.; Huuhtanen, M.; Keiski, R.L. The Effect of $\mathrm{NO}_{2}$ on the Activity of Fresh and Aged Zeolite Catalysts in the $\mathrm{NH}_{3}$-SCR Reaction. Catal. Today 2005, 100, 217-222. [CrossRef]

56. Konstantin, K.; Feng, G.; Libor, K.; Yong, W.; János, S. Molecular Level Understanding of How Oxygen and Carbon Monoxide Improve NOx Storage in Palladium/SSZ-13 Passive NOx Adsorbers: The Role of $\mathrm{NO}^{+}$and Pd(II)(CO)(NO) Species. J. Phys. Chem. C 2018, 122, 10820-10827. [CrossRef]

57. Yongwoo, K.; Sungha, H.; Jaeha, L.; YoungSeok, R.; Hyokyoung, L.; Chang, H.K.; Do Heui, K. Comparison of NOx Adsorption/Desorption Behaviors over Pd/CeO 2 and Pd/SSZ-13 as Passive NOx Adsorbers for Cold Start Application. Emiss. Control Sci. Technol. 2019, 5, 172-182. [CrossRef] 